\section{Commentary: Esophageal aperistalsis should not preclude lung transplant candidacy in well-selected patients}

\author{
Usman Ahmad, MD
}

Long-term survival after lung transplantation directly correlates with allograft function and is limited by chronic dysfunction. Because of relative shortage of transplantable organs, selection process for lung transplant candidacy has been geared toward excluding recipients with nonmodifiable risk factors for graft dysfunction or survival. ${ }^{1}$ Among others, such risk factors included certain malignancies, colonization with high-risk organisms such as resistant Burkholderia species, and nonmodifiable risk of aspiration.

With improvement in perioperative and supportive care, better understanding of organ dysfunction and management of some of these high-risk effects are now considered relative contraindications. Dysfunctional or absent esophageal peristalsis decreases the ability to clear esophageal contents and significantly increases the risk of aspiration. Furthermore, the options for antireflux procedures become limited because of weak or absent forward propulsion of food bolus. $^{2}$ Although this seems to be a setup for microaspiration and graft dysfunction, Miele and colleagues ${ }^{3}$ have previously shown reasonable 5-year survival in a cohort of patients with systemic sclerosis, $60 \%$ of whom had significant esophageal dysmotility.

In their report, Masuda and colleagues ${ }^{4}$ focus on the patients with complete aperistalsis documented by highresolution manometry and show that a subset will have improved motility after transplant and overall survival similar to that of patients with normal esophageal motility. Even patients whose motility did not improve ended up with reasonable survival. Their report is timely and important as

\footnotetext{
From the Department of Cardiothoracic Surgery, Heart and Vascular Institute, Cleveland Clinic, Cleveland, Ohio.

Disclosures: Author has nothing to disclose with regard to commercial support.

Received for publication March 4, 2020; accepted for publication March 4, 2020; available ahead of print March 19, 2020.

Address for reprints: Usman Ahmad, MD, Department of Cardiothoracic Surgery, Heart and Vascular Institute, Cleveland Clinic, Cleveland, OH 44195 (E-mail: ahmadu@ccf.org).

J Thorac Cardiovasc Surg 2020;160:1629-30 $0022-5223 / \$ 36.00$

Copyright (C) 2020 Published by Elsevier Inc. on behalf of The American Association for Thoracic Surgery

https://doi.org/10.1016/j.jtcvs.2020.03.011
}

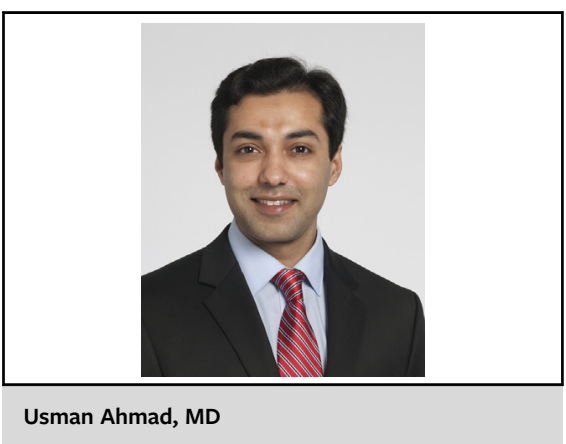

$$
\begin{aligned}
& \text { CENTRAL MESSAGE } \\
& \text { Absence of peristalsis does not } \\
& \text { exclude the possibility of lung } \\
& \text { transplantation in carefully } \\
& \text { selected patients. High-risk fea- } \\
& \text { tures should be taken into } \\
& \text { consideration in addition to HRM } \\
& \text { findings. }
\end{aligned}
$$

transplant teams continue to see more patients with connective tissue disorders who are more likely to have esophageal motility problems. It would be interesting to see how many patients with normal esophageal motility pretransplant ended up with dysmotility or aperistalsis post-transplant and what their survival outcome was.

What the data fail to show is the fact that all aperistaltic esophagi are not the same. The aperistaltic phenotype differs between connective tissue disorders (esophageal muscle disorder typically results in dilated lower esophagus, atonic lower esophageal sphincter) and motility disorders (higher lower esophageal sphincter pressure, dilated patulous esophagus). In lung transplant candidates, the former is most commonly encountered. In this context, highresolution manometry findings should be evaluated in the context of dysphagia and risk of aspiration. The following represent various clinical scenarios that can be found in lung transplant candidates with complete aperistalsis and represent different risks of dysphagia and aspiration:

1. Absent esophageal peristalsis but normal caliber esophagus and no clinical evidence of reflux or dysphagia

2. Absent esophageal peristalsis with severely dilated and patulous esophagus that may have air fluid levels in supine position, with or without reflux

3. Absent peristalsis with dysphagia, with or without reflux

Patients with preserved esophageal caliber likely have better emptying and may represent the group that has improved motility after transplantation. Drawing parallels 
from achalasia, such patients can even be considered for partial fundoplication if they have reflux and likely have a different survival trajectory compared with the other categories. Such differences should be taken into account in evaluating this patient population.

On the same note, we need to acknowledge the selection bias that is introduced by the transplant selection process. The patients reported were well selected and do not represent the general patient with aperistalsis. This is evident from the interesting finding that most patients in this series did not have severe acid reflux.

Overall, these results are encouraging and add to our understanding of esophageal dysfunction in the context of pulmonary transplantation. However, these findings should not mean carte blanche in offering transplantation to all aperistaltic patients because the nuances can significantly alter the outcomes.

\section{References}

1. Orens JB, Estenne M, Arcasoy S, Conte JV, Corris P, Egan JJ, et al; Pulmonary Scientific Council of the International Society for Heart and Lung Transplantation. International guidelines for the selection of lung transplant candidates: 2006 update-a consensus report from the pulmonary scientific council of the International Society for Heart and Lung Transplantation. J Heart Lung Transplant. 2006;25: 745-55.

2. Fisichella PM, Jalilvand A. The role of impaired esophageal and gastric motility in end stage lung diseases and after lung transplantation. J Surg Res. 2014;186:201-6.

3. Miele CH, Schwab K, Saggar R, Duffy E, Elashoff D, Tseng CH, et al. Lung transplant outcomes in systemic sclerosis with significant esophageal dysfunction. a comprehensive single-center experience. Ann Am Thorac Soc. 2016;13:793-802.

4. Masuda T, Mittal Sk, Csucska M, Kovacs B, Walia R, Huang JL, et al. Esophageal aperistalsis and lung transplant: recovery of peristalsis after transplant is associated with improved long-term outcomes. J Thorac Cardiovasc Surg. 2020;160:1613-26.
See Article page 1613 .

\section{Commentary: The return of peristalsis after lung transplant in patients with an aperistaltic esophagus - is it possible?}

\author{
Chi-Fu Jeffrey Yang, MD
}

Lung transplant candidates who have preoperative esophageal dysmotility are at an increased risk of having repetitive aspiration events that, after transplant, could lead to graft injury, bronchiolitis obliterans syndrome, and restrictive allograft syndrome. ${ }^{1}$ However, the short- and longterm outcomes of patients with esophageal aperistalsis who undergo lung transplant are largely unknown. How often do these patients have return of peristalsis after transplant? Do they have worse survival compared with patients with normal peristalsis? Should lung transplant

From the Department of Cardiothoracic Surgery, Stanford University Medical Center, Stanford, Calif.

Disclosures: Author has nothing to disclose with regard to commercial support.

Received for publication March 8, 2020; accepted for publication March 9, 2020; available ahead of print March 19, 2020.

Address for reprints: Chi-Fu Jeffrey Yang, MD, Falk Cardiovascular Research Center, 300 Pasteur Drive, Stanford, CA 94305 (E-mail: cjyang@ post.harvard.edu).

J Thorac Cardiovasc Surg 2020;160:1630-1

$0022-5223 / \$ 36.00$

Copyright (c) 2020 by The American Association for Thoracic Surgery

https://doi.org/10.1016/j.jtcvs.2020.03.009
Check for updates

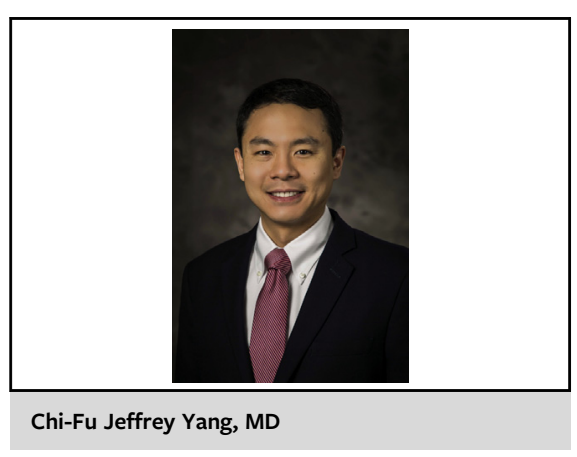

CENTRAL MESSAGE

Carefully selected patients diag-

nosed with an aperistaltic

esophagus before lung trans-

plant can have improved esoph-

ageal motility and reasonable

long-term survival after

transplant.

candidates with esophageal aperistalsis undergo lung transplantation?

In this issue of the Journal, Masuda and colleagues ${ }^{2}$ begin to answer these questions by reporting their experience at a single institution over 3 years (2013-2016). The authors compared the outcomes of 31 lung transplant recipients who had aperistalsis with those of 115 lung transplant 